\title{
Legalism: a turn to history in the anthropology of law
}

\section{Fernanda Pirie}

The problem of subject matter has been a recurrent theme in the anthropology of law. How do we identify what law is, in the absence of a state or centralized government, institutions for adjudication, professions, and officials? The unwritten rules and norms that regulate social interactions have often provided a focus for study, as have dynamics of conflict resolution. But does this adequately distinguish legal from other sorts of social norms and legal from other types of conflict resolution? Notorious definitional debates have, at times, characterized the field. Amidst these controversies, many anthropologists have simply pursued their own research agendas, studying legal phenomena in all sorts of contexts, most recently matters of regulation and government, justice, rights, and cultural property in the modern world. ${ }^{1}$ Difficult questions about the nature and definition of law have simply been ignored. But should they be left to the side?

Using empirical material and cross-cultural comparison to ask about the nature of social phenomena is at the heart of many anthropological projects. Ethnographic research produces detailed case-studies, which often challenge common assumptions about the nature, functions, and meanings of social forms - religion, marriage, the self, ethics, art, illness, and so on. Definition is rarely the point, but anthropologists often question, and suggest caution over, the concepts at play - the disparate phenomena to which the concept of 'religion' might be applied, for example, and the need for care when describing Hindu, Buddhist, or other beliefs and practices. ${ }^{2}$ In the case of law, anthropologists have revealed the unexpected consequences of legal activities, the subversion and creative adoption of legal rules and forms, and the role of laws in wider power relations. But their case studies raise deeper questions about the role that law plays within these processes. What is distinctive about the legal resources to which people turn? Why do they appeal to laws to pursue political agendas, legitimate nefarious activities, or try to make the world a better place? ${ }^{3}$ These questions can only be addressed by asking about the nature of law. What can law be and do?

Recently, an interest in combining the insights of anthropologists and historians has offered new approaches to these questions. Standing back from modern societies, scholars have sought out case studies from around the world and back in time to identify cross-cultural patterns amongst legalistic rules and practices. This has produced new insights into how and why laws come to be created, the different ways in which they are important, and what they can tell us about the societies in which they were made, used, and preserved. Careful comparison draws attention to the importance of legal texts, too often neglected in legal anthropology, and to the significance of the legal form. The focus has been on legalism, that is, generalizing rules and abstract categories, and the ways in which these are used to describe and organise the world. ${ }^{4}$

In this article I describe the importance of legalism as a social phenomenon. As an object of study, I argue, it highlights common themes and patterns amongst the wide variety of social phenomena we call 'law', providing a fruitful basis for cross-cultural comparison and for exploration of the nature, significance, and functions of law across different contexts. In the following sections I review some of the anthropological debates that have arisen about the nature of law, and then turn to case studies that illustrate the importance of legalism. Finally,

\footnotetext{
${ }^{1}$ M. Goodale, Anthropology and Law, New York, University Press, 2017.

${ }^{2}$ D. Gellner, "What is the Anthropology of Buddhist About?", Journal of the Anthropological Society of Oxford, 2, 1990, p. 95-112.

${ }^{3}$ These questions were raised by J. and J. Comaroff, “Introduction”, Law and Disorder in the Postcolony, Chicago, University Press, 2006.

${ }^{4}$ P. Dresch and H. Skoda (eds), Legalism: Anthropology and History, Oxford, University Press, 2012.
} 
I consider some of the ways in which comparison amongst such examples can shed light on the role of law in the complex processes of the modern world.

\section{The nature of law in legal anthropology}

In his pioneering work on the Trobriand Islands, Malinowski identified law in the unwritten rules and norms that govern social interactions. ${ }^{5}$ A well developed system of obligations and duties, he found, regulated the fishing activities of the South Pacific islanders, creating 'law, order and definite privileges'. ${ }^{6}$ Since they function in the absence of authority, government, and punishments, he argued, law is not only found in a body of rules imposed upon society and enforced by an independent authority. It may also consist of 'rules conceived and acted upon as binding obligations'. ${ }^{7}$ Later, he says that 'civil law' is 'the positive law governing all tribal life [which] consists of a body of binding obligations, regarded as right by one party and acknowledged as a duty by the other, kept in force by a specific mechanism of reciprocity and publicly inherent in the structure of society' ${ }^{8}$ This is to identify law in terms of its functions, namely, the regulation of social interactions. Indeed, Malinowski later declared that, 'law ought to be defined by function and not by form'. ${ }^{9}$

Anthropologists soon turned their attention to conflict, and the 1950s to 1980s produced many studies of mediation and other processes of conflict resolution. As Comaroff and Roberts noted, these scholars mostly approached conflict resolution as a social process, and focussed on the negotiation of individual rights and interests, rather than rule-dominated judicial activities. ${ }^{10}$ Finding law in the management of conflict is also, of course, to take a functionalist approach. In both cases, the subject matter is identified by what law does, rather than the form it takes. There is nothing particularly wrong with any of this-social norms and processes of conflict resolution are important-but it does expand the concept of law, identifying it in activities we would not ordinarily label as 'law'. It also tends to divert attention from the other sorts of things that law can be and do.

In the 1960s, a notorious and inconclusive debate between the legal anthropologists Max Gluckmann and Paul Bohannan about the use of English legal terms for the analysis of indigenous societies, seems to have deterred further debate about the concept of law. Indeed, Nader and Todd suggested that legal anthropologists should simply concentrate on processes of conflict resolution. ${ }^{11}$ As Greenhouse describes, the 'case method' was thought to be the most feasible means of discovering the rules, both literally and figuratively, that govern a population. ${ }^{12}$ However, although this produces a detached display of problematic social relations in cultural contexts, she argued, it also tends to obscure important distinctions between rules and other normative formulations. ${ }^{13}$

Anthropological interest in law did not disappear, however, and the field was given new impetus by Griffiths's call to study 'legal pluralism'. ${ }^{14}$ The term had already been used by

\footnotetext{
${ }^{5}$ B. Malinowski, Crime and Custom in Savage Society, London, Kegan Paul, 1926.

${ }^{6}$ Ibid. p. 21

${ }^{7}$ Ibid. p. 15

${ }^{8}$ Ibid. p. 58

${ }^{9}$ B. Malinowski, “Introduction”, Law and Order in Polynesia, H.I. Hogbin (ed.) London, Christophers, 1934, p. lxiii.

${ }^{10}$ J. Comaroff and S. Roberts, Rules and Processes: The Cultural Logic of Dispute in an African Context, Chicago, University Press, 1981.

${ }^{11}$ L. Nader and H.F. Todd, The Disputing Process: Law in Ten Societies. New York, Columbia University Press, 1978.

${ }^{12}$ C. Greenhouse, Praying for Justice: Faith, Order, and Community in an American Town, Ithaca, Cornell University Press, 1986, p. 29.

13 Ibid. p. 30-31.

${ }^{14}$ J. Griffiths, “What is Legal Pluralism?” Journal of Legal Pluralism, 1986, 19, p. 1-47.
} 
Franz von Benda-Beckmann, among others, ${ }^{15}$ but Griffiths argued for its more widespread application, in order to identify and describe the subject matter of empirical legal studies. Inspired by Moore's work on the 'semi-autonomous social field'-a study of unwritten working practices amongst garment-traders in New York ${ }^{16}$ —he declared that what Moore had been describing was a case of legal pluralism, that is, the coexistence of two or more legal systems in one society. The implication was that scholars should study non-state norms as forms of law. A great deal of excellent work, and a journal with the name, have resulted, but the popularity of the concept reignited definitional debates. ${ }^{17}$ Fuller has argued that the coexistence of plural legal or normative orders is a universal fact of the modern world, so the concept points to nothing distinctive. ${ }^{18}$ The implicit broadening of the concept of law and the lack of any satisfactory attempt to define its consequent ambit has attracted even stronger criticism. In an article largely supportive of the project, Merry asked 'where do we stop speaking of law and find ourselves simply describing social life?' ${ }^{19}$ More critically, Roberts has argued that the extension of the term to 'negotiated orders' is problematic: to characterize the understandings and practices of stateless societies as legal orders and embrace all normative universes as equivalent, he says, does not tell us much of what we might want to know about any of them. ${ }^{20}$ As Fuller points out, we are liable to fail to identify the distinguishing features of 'law', properly so called, as well as attributing negotiated orders with the characteristics of law-centred models. ${ }^{21}$ Our concept of law has a specialized and differentiated character, Roberts argues, so the result is a loss of analytic purchase. There is much force in these critiques.

Valuable anthropological work has continued under the label of legal pluralism, although some scholars have modified their positions from the bold claims of earlier days. Griffiths has argued that socio-legal scholars should simply study the diverse forms of normative ordering that arise in the world, without being concerned to distinguish legal from other orders. $^{22}$ Meanwhile Tamanaha—also apparently changing his position, albeit from the opposite starting point—has argued that our analysis should not be limited to what can definitively be regarded as law. Rather, he says, it should start with a typology of social orders and continue with a typology of laws - state, customary, religious, international, indigenous, and natural. ${ }^{23}$ The field should not, then, be limited by any definitional issues. This is surely right, when it comes to identifying what the anthropologist might study. It does, however, leave open the question of whether there is anything distinctive about legal orders, forms, and processes. It avoids the question of what law is.

Outside these debates, anthropologists have largely avoided questions of definition, while exploring the different ways in which law can be used and abused in the modern world. There has been interest in the new spaces and processes opened up by contemporary developments,

\footnotetext{
${ }^{15}$ F. von Benda-Beckmann, Rechtspluralismus in Malawi: geschichtliche Entwicklung und heutige Problematik, München, Weltforum Verlag, 1970.

${ }^{16}$ S.F. Moore, "Law and Social Change: the Semi-Autonomous Social Field as an Appropriate Subject of Study”, Law and Society Review 7, 1973, p. 719-46.

17 B. Tamanaha, “The Folly of the 'Social Scientific' Concept of Legal Pluralism”, Journal of Law and Society, 20, 1993, p. 192-217; S. Roberts, “Against Legal Pluralism: Some Reflections on the Contemporary Enlargement of the Legal Domain”, Journal of Legal Pluralism, 42, 1998, p. 95-106; S. Roberts, “After Government: On Representing Law Without the State”, Modern Law Review, 68, 2005, p. 1-24.

${ }^{18}$ C.J. Fuller, “Legal Anthropology, Legal Pluralism and Legal Thought”, Anthropology Today, 10, 1994, p. 912.

${ }^{19}$ S.E. Merry, “Legal Pluralism”, Law and Society Review 22, 1988, p. 869-96, at p. 878-79.

${ }^{20}$ Roberts, “After Government”.

${ }^{21}$ Fuller, "Legal Anthropology, Legal Pluralism and Legal Thought”, p. 10.

22 J. Griffiths, "The Idea of Sociology of Law and its Relation to Law and to Sociology”, Law and Sociology, M. Freeman (ed.) Oxford, University Press, 2006.

${ }^{23}$ B. Tamanaha, A General Jurisprudence of Law and Society, Oxford, University Press, 2001, ch. 8.
} 
such as the popularity and use of human rights laws and arguments, new procedures in international justice, intellectual and cultural property regimes, the laws and legal processes that govern migration, patterns of legal inclusion and exclusion, the effects of laws on gender and reproductive practices, transnational laws, and so on. Goodale, in his review of the field, emphasizes the different ways in which laws can produce meaning and establish identities, as well as the ways in which they regulate and shape action. ${ }^{24}$ What he, and others, do not do, however, is offer any account of what distinguishes legal from other forms and processes, nor what unites these disparate phenomena. What is it about law that enables it to perform so many functions? Law may be an instrument 'to legitimize the take', as Nader has maintained, but it is also used by the relatively powerless to pursue claims against those who would expropriate their resources. ${ }^{25}$ Do human rights laws necessarily reinforce the role of the neoliberal state, as Speed suggests? ${ }^{26}$ If so, why do indigenous groups adopt the language of the law to call for justice against those same states? Laws are developed to stabilize social relations, but they can also act as agents of exclusion. ${ }^{27}$ What is it about law that makes it attractive and effective in many circumstances, despite its abject failure to live up to the promise of justice in others? Although the Comaroffs raised many of these questions, they have barely been addressed in subsequent scholarship. ${ }^{28}$ To begin to answer them, we need to focus on what is distinctly legal about the instruments, structures, and processes involved. Questions about the nature of law cannot be avoided.

\section{Legalism}

In critiquing the concept of legal pluralism, Roberts has argued persuasively that it is important to distinguish legal rules and structures from 'negotiated orders'. ${ }^{29}$ To do so, he maintains, we must recognize that the concept of law is linked firmly with centralized government. Law emerges, he argues, when a political configuration centralizes power, using command as a means of decision-making; when it formulates ideological justification for its authority and articulates rules, followed by attempts to achieve compliance with them and the establishment of adjudicative agencies. ${ }^{30}$ This draws a firm line between legal and negotiated orders. However, as I have argued elsewhere, some case-studies suggest that distinctly legal phenomena can also be produced by tribal societies without centralized governments. ${ }^{31}$ The burgeoning studies of human rights and other forms of international and transnational laws lend further support to this argument. ${ }^{32}$ If law is not firmly tied to centralized government, then how are we to recognize and distinguish it?

In a series of related publications, anthropologists and historians have demonstrated that a focus on 'legalism' can be used to explore the distinctive nature of law. ${ }^{33}$ Legalism refers to

\footnotetext{
${ }^{24}$ Goodale, Anthropology and Law.

${ }^{25}$ L. Nader, “The Americanization of International Law”, Mobile People, Mobile Law, F. and K. von BendaBeckmann and A. Griffiths (eds), Aldershot, Ashgate, 2005, p. 199.

${ }^{26}$ S. Speed, "Exercising Rights and Reconfiguring Resistance in the Zapatista Juntas de Buen Gobierno", The

Practice of Human Rights, M. Goodale and S. Merry (eds), Cambridge, University Press, 2007, p. 176-78.

${ }^{27}$ F. Pirie and J. Scheele, “Justice, Community, and Law”, Legalism: Community and Justice, Oxford, University Press, pp. 1-24, at p. 21-23.

${ }^{28}$ J. and J. Comaroff, "Introduction”, Law and Disorder in the Postcolony.

${ }^{29}$ Roberts, “After Government”.

${ }^{30}$ Ibid. p. 14.

${ }^{31}$ F. Pirie, “Law Before Government: Ideology and Aspiration”, Oxford Journal of Legal Studies, 30, 2010 , p. 207-28.

${ }^{32}$ M. Goodale and S.E. Merry, The Practice of Human Rights: Tracking Law Between the Global and the Local, Cambridge, University Press, 2007; S.E. Merry, “Anthropology and International Law”, Annual Review of Anthropology 35, 2006, p. 99-116; A. Riles, “Collateral Knowledge: Legal Reasoning in the Global Financial Market”, Chicago, University Press, 2011.

33 The principal publications are: Dresch and Skoda, Legalism: Anthropology and History; Pirie and Scheele,
} 
the use of generalizing rules and abstract categories to describe the world and to order community and social life. It is typically found in written rules and law codes, although oral rules might also be explicit and enduring in similar ways. The concept of legalism does not serve to define what law is - the category of law is too heterogeneous for neat definition-but it draws anthropological attention to important and distinctive characteristics amongst empirical examples. It serves to distinguish law from negotiated orders, while also avoiding a close association between law and the state or centralized government. Legalistic rules are not always part of an organized legal system, so the concept may not serve to distinguish these sorts of laws from the rules of cricket - to use an example beloved of legal theoristsbut this should not trouble the anthropologist interested in explaining empirical legal phenomena. Laws and rules often share important features.

As I describe below, a focus on legalism highlights important cross-cultural patterns as well as explaining the widespread appeal of law to different people in different contexts. This, in turn, draws our attention to the importance of what might be called 'idealism', namely the tendency for law to represent or invoke higher ideals or standards. Together, I suggest, these features explain much about what law is and does. Three examples from the Tibetan plateau will illustrate these points.

\section{Tibet}

Historic Tibet has not often features in legal studies, largely because it had no organized legal system. In the seventh to ninth centuries, most of the plateau was controlled by a centralized regime, under kings who styled themselves as emperors and successfully united a number of powerful and warlike tribes. They established a bureaucracy, made laws, and adopted Buddhism. However, after the regime collapsed in the ninth century, political organisation remained fragmented for several centuries and the outlying areas- the subject of the first two case studies below-were not brought firmly under central governmental control again. It is the absence of organised law that makes them anthropologically interesting, however.

\section{Ladakh: refusing law in a legalistic world}

At the western end of the Tibetan plateau, Ladakh was linked to greater Tibet through language, religion, and trade, since the days of imperial expansion. An independent kingdom until it fell under Kashmiri control in the 1840s, it is now part of the Indian state of Jammu and Kashmir. Its villages form isolated patches of irrigated agriculture in a mountainous, sparsely-populated desert, and their inhabitants, who rarely number more than 1,000 , are still largely dependent on subsistence farming. The region is now administered by civil servants based in the regional capital, Leh, but in practice, village affairs are still very much managed locally, under the direction of village councils.

The aim of my original research was to investigate processes of conflict resolution conducted at village level. ${ }^{34}$ It quickly became apparent that the villagers were inclined to deal with all disputes as internal matters, and even a suspected murder had been kept from the attentions of the police. They promoted internal conciliation. But there were no rules or laws dealing with 'offences': a fight, or even a case of 'rape', was regarded primarily as the cause of problematic relations between two households, which could be resolved through the shaking of hands and payment of a fine to the village. It was not an event involving an

\footnotetext{
Legalism: Community and Justice; P. Dresch and J. Scheele (eds), Legalism: Rules and Categories, Oxford, University Press, 2015; and G. Kantor, T. Lambert, and H. Skoda (eds), Legalism: Property and Ownership, Oxford, University Press, 2017; as well as F. Pirie, The Anthropology of Law, Oxford, University Press, 2013.

${ }^{34}$ I undertook ethnographic fieldwork, primarily in one village, over several lengthy periods from 1999 to 2008. See, F. Pirie, Peace and Conflict in Ladakh: The Construction of a Fragile Web of Order, Leiden, Brill, 2007. I also conducted fieldwork in eastern Tibet, described later, from 2003.
} 
'offender', 'victim', or 'rapist'. ${ }^{35}$ Without referring to any rules or legal categories to address disputes or discipline those guilty of aberrant behaviour, the villagers' responses to conflict were dominated by a concern to avoid the consequences of overt conflict and antagonism. Rather than regarding a dispute in terms of a clash of rights, they saw it as a tear in the fabric of the community, which had to be mended with the payment of fines and a ceremonial process of reconciliation.

Ultimately, it was the village meeting, organized by the headman and attended by all adult men, that was responsible for resolving the most serious disputes. It did so by promoting reconciliation, which generally involved apologies, presentation of ceremonial white scarves, and the pouring out of local beer from brass jugs, although fines were occasionally paid 'to the village, for the fight'. Intense moral pressure was put upon quarrelling parties to shake hands and forget their disputes, and an individual who failed to apologize for a quarrel might be threatened with a social boycott. The villagers' responses to a case of 'stubbornness', as they put it, were directed at the need to restore peace and harmony in the village, through apologies and gestures of conciliation. These practices of conflict resolution were obviously linked to, and shaped by, ideas about anger and antagonism. A strong sense of civic morality supported the micro-political organization of the village and its social structures: complex relations between households, strategies for maintaining relations of equality, and methods for distancing all manner of outsiders from village affairs.

The village meeting never resolved conflict by applying rules to determine a correct outcome or appropriate punishment, then. However, it did occasionally formulate new rules. At one point, the villagers decided that every household should send its second son to the monastery. However, this rule was not consistently followed or enforced. Failure to comply was presented as a matter of regret, not subject to sanctions: the new rules were not regarded as having any authority in themselves. There were also unwritten customs, which the Ladakhis refer to as trim. ${ }^{36}$ These were explained as things that 'we do'-ways of cooking, dressing, organizing festivals, managing property and household relations. They were constantly affirmed in everyday conversation, but never debated or regarded as being in issue during processes of conflict resolution. Occasionally, when a dispute involved something like a property boundary, the headman recorded the final agreement in writing, but this was not systematic, and the documents were rarely, if ever, referred to in subsequent cases. The villagers did not take a legalistic approach to conflict, that is. The community as a social whole, had to be repaired, and order did not need to be imposed through law, even internallygenerated rules.

This refusal of legalism is all the more striking given that many of the villagers are literate and the community forms part of the sophisticated cultural world of Buddhist Tibet, which is replete with texts, rules, and documentary practices. They are not like the Trobriand Islanders, who did not use writing for any purposes. The villagers' lack of written rules, a constitution, or case records begins to look like a deliberate rejection of legalism. The Ladakhis could perfectly well formulate laws, so why do they not do so? Other quite smallscale communities, including medieval Icelanders, early Irish societies, and villages in contemporary Algeria, have elaborated complex legal codes and constitutions. ${ }^{37}$ These

\footnotetext{
${ }^{35}$ F. Pirie, The Fragile Web of Order: Peace and Conflict in Ladakh, DPhil diss. University of Oxford, 2002, p. 253-56.

${ }^{36}$ This is the phonetic transcription of the Tibetan word, khrims, used in other contexts to refer to law-like rules, as described in the following section.

${ }^{37}$ W.I. Miller, Bloodtaking and Peacemaking: Feud, Law, and Society in Saga Iceland, Chicago, University Press, 1990; M. Gerreits, "Money in Early Christian Ireland according to Irish Law", Comparative Studies in Society and History, 27, 1985, p. 323-39; J. Scheele, “A Taste for Law: Rule-Making in Kabylia (Algeria)”,
} 
examples raise interesting questions about the attraction of laws that do not seem to have been applied directly, but they also throw into relief the distinctive nature of the Ladakhi communities, which do not resort to legalism to organise their communal lives.

In practice, of course, to posit a reason for the refusal of legalism can only be a matter of speculation-it is impossible to elicit a meaningful response from the villagers, themselves. They merely shrug their shoulders and look puzzled that someone should be asking about written rules. But we might compare their unwillingness to judge one another. The villagers are very reluctant to voice open criticism. They express disapproval and make disparaging remarks about neighbours who perform village duties badly, or fail to maintain their fields and households properly-they even disparage those who openly display displeasure or take offence-but such attitudes are expressed subtly and privately. The villagers do not hold each other openly to account. As I have discussed elsewhere, this largely explains the failure of simple electoral processes introduced into many Ladakhi villages under the panchayat system of local government and demanded by development organizations for the management of their projects. ${ }^{38}$ Instead of promoting a collective spirit, these committees have often led to the concentration and abuse of power in the hands of a few. The problem is that for a system of elected representation to work well, bad leaders must be judged and publicly removed from office. Yet, as Ladakhis themselves acknowledge, they are reluctant to criticize one another openly: 'If you talk at night, you will not be heard', as one put it to me, explaining why his village had not removed a corrupt leader. Laws provide standards against which behaviour can be judged, because they have an existence independent of the particularity of daily life; explicit rules can make it easier for people to reach decisions. But applying a rule means that behaviour must be openly adjudged to be good or bad, right or wrong. The Ladakhis prefer to address problematic behaviour as a disruption to social order, which can be put right through a process of conciliation. They do not want to mete out punishment on those who have infringed village rules. ${ }^{39}$

Much more could be said about this example, which I have discussed extensively elsewhere, ${ }^{40}$ but its significance for the present article is that these questions and insights only come into focus if we appreciate that the villagers maintain order and resolve disputes without resorting to legalism, that is, without creating explicit rules and standards and judging each other against them. These processes are distinct from their unwritten customs, the trim, which are barely law-like, and their explicit rules, which are mostly not enforced.

\section{Eastern Tibet: formulating rules for tribal feuds}

At the other end of the Tibetan plateau, some two thousand miles to the east, the grasslands of Amdo are home to nomadic pastoralists, who move around with herds of yak, sheep, and goats. The region was not politically unified before it was incorporated into the Chinese state in 1958: from the eighteenth century the representative of the Qing emperor, his Amban, exercised some influence in the region, but local rulers governed their own polities, while major monasteries appointed headmen to groups of surrounding tribes.

\footnotetext{
Comparative Studies in Society and History 50, 2008, p. 895-919.

${ }^{38}$ F. Pirie, "Rules, Proverbs, and Persuasion: Legalism and Rhetoric in Tibet”, Legalism: Rules and Categories, F. Pirie and J. Scheele (eds), Oxford, University Press, pp. 108-28, at p. 248.

${ }^{39}$ One might also speculate that, at some deeper or unconscious level, Ladakhi villagers have wanted to avoid the danger of external powers taking control of their small community, by adopting and enforcing, or altering, their laws, as happens elsewhere: G. Bédoucha, Geneviève. "Libertés coutumières et pouvoir central: l'enjeu du droit de l'eau dans les oasis du Maghreb”, Études Rurales 155/156, 2000, p. 117-41. This would also be consistent with their resistance to development initiatives, F. Pirie, “Doing Good Badly, or at all?” Ladakh Studies, 17, 2002, p. 29-32.

${ }^{40}$ Pirie, Peace and Conflict; F. Pirie, “Community, Justice, and Legalism: Elusive Concepts in Tibet”, Legalism: Community and Justice, Pirie and Scheele (eds).
} 
The tribes in Golok (the southwestern part of Amdo) had hereditary ruling families and were notorious for their ferocity and independence. Relations amongst them were, and still are, governed by dynamics of vengeance and retaliation. Tribal groups pursue feuds, which sometimes escalate into dramatic and long-running conflicts. Anyone who has suffered an insult is expected to get angry and retaliate, and family members, encampments, and tribes are expected to combine to face a common opponent. There are also expectations of restraint, however, and open violence inevitably leads to an elaborate form of mediation. This can involve meetings lasting for several days, characterized by extensive argument and flamboyant oratory. The object is to negotiate a suitable amount of blood money and compensation for damage and injuries, depending on issues of status and the gravity of the injury. High-status headmen or Buddhist lamas may preside, but cases are negotiated on their own terms, with reference to historic relations and arguments about status and reputation. There is no question of applying rules and parties can, and do, walk away from the negotiations, leading to apprehension of renewed hostilities. Although the revenge relations that underlie these processes form a striking contrast with the social expectations of the Ladakhi villagers, who frown upon all forms of violence and revenge, the processes of conflict resolution are similar in that they take the form of negotiation and mediation, rather than adjudication according to law-like rules. Nor is there any centralised authority in Golok able or expected to enforce a settlement. Social pressure is placed on disputants to agree to a solution, and once that is done, peace is largely restored, even if resentment still lingers. These practices have a long history, as is evident from accounts of the early twentieth century. ${ }^{41}$

This would seem to be an unlikely context in which anyone would think to elaborate a lawcode, but this is what the Golok tribespeople have done. A number of the mediators amongst whom I worked referred to their tribes' laws, their trim, while explaining how conflict was resolved. Although the same word is used in Ladakh to refer to unwritten customs, the mediators were here referring to law-like rules, which they recited and explained in some detail. The rules concerned payments - in horses and guns - that must be made to secure a truce, and further payments - calculated in yaks, horses, guns, and silver coins - that should count as adequate compensation in different cases. These rules reflected the basic pattern of conflict resolution they had already described, with exchanges leading to the calling of a truce and amounts to be paid for different sorts of damage. However, they were specific, and also far more elaborate, than the principles actually applied during processes of mediation. In particular, the rules divided people into three different categories-high, middle, and low-marked by different amounts of blood money and different types of animal. In practice, although mediation involves arguments about reputation and status, explicit social distinctions are not referred to, let alone any tripartite hierarchy.

The mediators explained that each of the Golok tribes has its own laws, and that these are similar in content - the headmen apparently used to gather to discuss them. At least one tribe had also written its rules in a law-book. The old texts were destroyed during the Cultural Revolution, they explained, but this code had subsequently been reproduced from oral accounts in a publication on the history of the region. ${ }^{42}$ The written version closely reflected the laws described by the mediators. Many, in turn, reflected the practices described by local informants, including the giving of a horse and gun to secure a truce, as well as the fact that the appropriate amount of compensation depends on the status of the victim. But, like the

\footnotetext{
${ }^{41}$ R. Ekvall, "Peace and War among the Tibetan Nomads", American Anthropologist, 66(5), 1964, p. 119-48. The administration of the modern Chinese state, of course, complicates these dynamics, but this is beyond the scope of this article.

${ }^{42}$ Mgo log rig gnas lo rgyus (A history of Golok culture), Golok Prefecture Committee for Historical Research, 1991.
} 
rules recited by the mediators, the rules in the published code are precise, detailed, legalistic, and complicated, in striking contrast to accounts of mediation practice, both contemporary and historical. ${ }^{43}$ What, then, were they for?

In practice, compensation is always a matter of negotiation, the outcome of long processes — often days — of argument and rhetoric in front of respected mediators. Informants from different parts of the region uniformly emphasized the importance of oratory and Golok advocates are renowned for their use of specialized maxims and proverbs, with which they expound upon the honour and status of the families involved. The most renowned orators can baffle opponents from other regions, they claim, using obscure proverbs and metaphors. During the course of numerous conversations, none of the mediators suggested that the written laws were referred to directly during these processes. Informants were usually evasive when asked about them, although no-one in Golok dissented from the fact that their laws were important. They are reproduced in modern printed editions, talked about by mediators, and recognized by other tribes, who claim they maintain their own, similar laws. The contrast between the specific, generalizing rules of the law-code and the allusive and metaphorical rhetoric of mediation practice is striking. Rules can ostensibly be applied to facts at hand to produce a definite answer; proverbs are more suited to persuasive argument, 'impressing the mediators', as one put it, pushing the outcome in one direction or another, rather than allowing for a definitive judgement. The rules of the code seem irrelevant to the argument that, in practice, characterizes the mediation processes.

How, then, should we understand them? We need to separate their form from their application. As I have argued elsewhere, we need to ask about their symbolism, about what they stand for. ${ }^{44}$ The code is made up of precise rules, but these, in turn, indicate general principles: they elaborate a status hierarchy, affirm basic principles of loyalty and revenge, and - in a general sense-confirm when it is appropriate to accept compensation to settle a feud. They are also presented as if they have, and always had, an independent existence, a matter of specialist knowledge, the preserve of the mediators and tribal leaders. In these ways, they represent what it is right for tribesmen to do: the fact that it is proper to accept compensation in lieu of taking revenge, and on what principles it should be calculated; the fact that it is right, because honourable, for an injured and affronted tribesman to set aside his anger and accept amends. The trim seem to have more ideological or symbolic, than practical, value. In a similar way, a lengthy introduction to the code refers to the history of central Tibet and the religious basis of its early laws, which are said to have inspired the authors of the code. This is to represent the participation of the Golok tribes in the wider world of Tibetan civilization, with its Buddhist foundations. It indicates that they share a common cultural history with the rulers and monasteries of central Tibet, their lamas and patrons. This is significant in a region where the tribes always fiercely guarded their independence from the control of the Dalai Lamas in Lhasa, as much as the Amban answerable to Beijing. The code is important for what it expresses, then, in terms of the moral principles that shape the pastoralists' world and the ideals of respect and recompense that allow them to address conflict, while also insisting on individual status and independence.

The rules of this code are mostly explicit and precise, that is, legalistic. As anthropologists we might still ask whether this is an example of law. But what are they if not laws? Their precise and categorical nature distinguishes them from the indefinite, allusive, metaphorical rhetoric of mediation practices. They stand apart from practice, articulating rules and principles in categorical terms. Unlike the Ladakhi case, where the trim are barelyarticulated customary practices, to call the written trim of Golok anything other than 'laws'

\footnotetext{
${ }^{43}$ They also cover 'the arts of war', with rules about how contributions to the war effort (we should understand tribal conflict) are to be made by different families, again distinguished by status.

${ }^{44}$ Pirie, "Law Before Government".
} 
would stretch normal language. Comparable phenomena have been described by anthropologists working amongst tribal groups elsewhere: nomadic pastoralists in northern Yemen wrote documents and rules, which the anthropologist Paul Dresch describes as their 'laws'. The Yemeni laws stood for justice and order, expressed solidarity, and made explicit fundamental relationships of protection and guarantee. ${ }^{45}$ At the very least, these codes are on the fringes of what we might reasonably call law, and this, in turn, makes them good examples with which to explore our own concepts. Why does it seem difficult to say what the Golok rules could be, if not a set of laws? It is obviously their form that makes them hard to label in any other way. By contrast, processes of mediation and the norms and customs of the Ladakhi villagers can be described in other terms. If the code is law-like, this is because of its form as precise and explicit rules and the ways in which they categorize behaviour, that is, its legalism.

Much more could be said about the social and legal practices of the Golok tribespeople, as I have done elsewhere. ${ }^{46}$ The significance of the example, for present purposes, lies in the fact that it draws attention to the importance of legalism amongst the phenomena we think of as law. It also highlights the fact that laws may be recognized as important and authoritative, despite not being guaranteed by any political institution or even applied or enforced. They may not be directly invoked in the mediation of conflict, but they evoke higher ideals and make external standards explicit. It is this that I have elsewhere called their 'idealistic' aspects. ${ }^{47}$ It is a feature of law that it is too easy to overlook if we focus primarily on the regulation of behaviour and resolution of disputes.

\section{Law in historic Tibet}

A final case-study exemplifies the variable and shifting meaning of the concept of trim in historic Tibet, shedding further light on the combination of legalism and idealism that characterizes these examples of law.

There was nothing resembling an established or bureaucratic legal system throughout most of Tibet's history. ${ }^{48}$ The exception is the empire of the sixth to ninth centuries AD, when the Tibetan kings established a royal court, creating a system of ranks and offices, complex bureaucratic practices, and written laws. Records from this period are sparse, but historians have identified fragments of legal texts, from which it is clear that Tibetans both made laws and instituted legal processes with considerable procedural complexity. ${ }^{49}$ Some of the surviving laws are highly legalistic: they provide for compensation payments to be made in the case of injuries on the hunting field, carefully distinguishing between the ranks of both offender and victim, which are marked by a hierarchy of payments. As I have argued elsewhere, these laws seem unrealistically complicated and, like the Golok code, can hardly have been applied in any detail. ${ }^{50}$ They seem to have been more important for what they represented, making the aristocratic status hierarchy explicit, rather than determining precise amounts of compensation. They also exemplify the idea that deliberate and accidental injuries

\footnotetext{
${ }^{45}$ P. Dresch, The Rules of Barat: Tribal Documents from Yemen, Sanaa, Centre français d'archéologie et des sciences sociales, 2006.

46 Pirie, "Law Before Government”, “Rules, Proverbs, and Persuasion”.

${ }^{47}$ Pirie, The Anthropology of Law, ch. 9.

${ }^{48}$ Consequently, little has been written about law in historic Tibet. The exceptions are R.R. French, The Golden Yoke: The Legal Cosmology of Buddhist Tibet, Ithaca, Cornell University Press, 1995, on the cosmological aspects, and work by Tibetanist scholars, notably the many publications of Dieter Schuh, on agreements, court records, and other documents.

${ }^{49}$ B. Dotson, "Introducing Early Tibetan Law: Codes and Cases”, Secular Law and Order in the Tibetan Highland, D. Schuh (ed.) Andiast, International Institute for Tibetan and Buddhist Studies, 2015.

${ }^{50}$ F. Pirie, "Oaths and Ordeals in Tibetan Law", Secular Law and Order in the Tibetan Highland, D. Schuh (ed.) Andiast, International Institute for Tibetan and Buddhist Studies, 2015, p. 177-95.
} 
ought to be treated differently, probably establishing principles to be applied by analogy in other cases. ${ }^{51}$ Like the Golok code, then, these laws are legalistic, without having been applied directly in the resolution of disputes. It is evident that there were distinct procedural rules which governed the stages of a judicial process, the giving of evidence, and the role of guarantors.

The structures of the empire, and with them the bureaucracy of the judicial system, substantially collapsed in the mid ninth century, for reasons that are still not entirely clear. ${ }^{52}$ Several centuries of political disunity followed, known as 'the age of fragments' by Tibetans. Local rulers established small polities, but power gradually coalesced around the monastic institutions, which developed into substantial seats of wealth and learning. From here, Tibetans set off over the Himalayas to study and translate ancient Buddhist texts, and to invite Indian scholars back to their monasteries. Although Buddhism had been adopted as the state religion by the early Tibetan kings, this second wave of translation work gave it a new impetus. It also prompted Tibetan scholars to rethink the nature of their polity, which they now envisaged as founded upon Buddhist principles.

Between the eleventh and twelfth centuries, a succession of writers, most monastically trained, produced a set of narratives in which they describe the history of their religion, their state, and its kings and scholars. ${ }^{53}$ Central to most of these accounts was law, trim. In what became a standard narrative, they described how the first Buddhist kings made a set of laws based upon the ten principles of Buddhist morality and, in this way, brought peace and stability to their kingdom, as well as ensuring moral behaviour, and hence good rebirth, on the part of their people. These 'royal laws' were said to be closely related to the 'religious laws', implicitly the rules of Buddhist morality. Subsequent periods of disruption, involving the persecution of religious practitioners, were described as times in which these laws were disregarded - they disintegrated like a rope of rotten hay, in one evocative metaphor. These narratives never set out what the laws were supposed to have been in any detail: some of them mention practices of compensation for theft and injuries, oath-taking, and mutilation penalties for sexual misconduct, probably reflecting contemporary practices; some suggest that the trim were rules for personal discipline, supposed to ensure that people followed the principles of Buddhist morality. In this, they were almost certainly inspired by the Vinaya, the elaborate code of Buddhist monastic discipline, created in India, which had been translated into Tibetan. As a matter of presentation, therefore, while the imperial administration had used the concept of trim to refer to legalistic rules and administrative practices, now writers were deploying it within idealistic accounts about the foundation of the Buddhist polity. It here came to refer to rules of personal discipline, based on the moral principles of Buddhism.

In the thirteenth century Tibet came under the influence of the Mongols and was incorporated into their Yuan empire. The new administrators introduced bureaucratic and documentary practices, along with postal systems and standardized ways of recording political agreements and taxation arrangements. Tibetans now came to use the concept of trim to apply to the power and administration of their imperial over-lords. There is no evidence that the Yuan legal code, itself, extended to Tibet, but these experiences seem to have inspired Tibetan writers to rethink their ideas about law. After the collapse of the Yuan empire, in the late fourteenth century, Tibet was able to establish a measure of political

\footnotetext{
${ }^{51}$ Dotson, "Introducing Early Tibetan Law”.

${ }^{52}$ Historical details in this section are largely drawn from: M. Kapstein, The Tibetans, Oxford, Blackwell, 2006; S. van Schaik, Tibet: A History, London, Yale University Press, 2011; and L. Petech, Central Tibet and the Mongols, Rome, IsMEO, 1990.

${ }^{53}$ F. Pirie, "Buddhist Law in Early Tibet: The Emergence of an Ideology" Journal of Law and Religion, 32, 2017, p. *.
} 
independence under the much lighter control of the Ming regime, and a member of what was then the most powerful family, the Pagmodru, wrote a treatise about law entitled The Mirror of the Two Laws. ${ }^{54}$ This was probably part of a project to systematize legal practices and consolidate political power, on the part of the Pagmodru. However, the writer obviously thought it important to link this ambition to the idealistic accounts of law found in the historical narratives.

In the opening sections of the treatise, he discusses and explains the ten Buddhist moral norms, employing short morality tales to explain 'the law against killing', and so on, implicitly the 'religious laws'. He then explains that both religious and royal laws have the same purposes, namely the entrenchment of Buddhist morality. In two following sections he describes 'the application of the royal law'. ${ }^{55}$ The second of these consists of fifteen 'edicts', which describe the ways in which judges and mediators should deal with disputes. It deals in turn with cases involving killing, injuries, stealing, lying, sexual misconduct, divorce, loans, and so on. There are also general provisions about weights and measures and court fees. In subject matter, the first five of these edicts mirror the first five of the ten Buddhist moral principles. However, they are concerned with the practical business of conflict resolution, describing compensation payments for injuries, how divorce should be managed, and the oaths that might be employed to test the truth of evidence. They do not articulate matters of personal morality. Indeed, the edict on killing recites rule-like directions for compensation, prescribing specific amounts of blood money for people of different status. These seem to reflect the old legal codes, which may still have been known or remembered by Tibetans. However, the nature of the currency and status distinctions they specify are obscure, giving these provisions a schematic character. The provisions concerning fines, compensation payments, and the small payments due to the imperial administration are also expressed in rule-like terms. However, the text often notes that it is reflecting what the 'elders and wise people' say. It recognizes that mediators had to negotiate settlements, rather as they do today in Golok, and places considerable emphasis on the qualities of honesty, thoroughness, care, and judgement required of them. It seems very much as if the writer has conducted or commissioned a survey of mediation practices, identifying common principles and indicating approval of certain practices.

It seems highly unlikely that these, or any other laws, were applied systematically during this period. The text repeatedly recognizes the autonomy and skill of the mediators in negotiating compensation. The edict on lying, for example, contains a lengthy discussion of the directions a mediator might give if there is a disputed allegation of theft, when an oath might need to be strategically administered. It is more of an advice on best practice than a set of explicit rules. The idea that the Tibetan trim were disciplinary rules based on moral principles has, that is, been reworked to reflect the pragmatic and non-legalistic nature of contemporary mediation practices. There is no evidence of how this treatise might have been used and there are no references to it in surviving texts from this period. However, in the early seventeenth century, its contents appear to have inspired the writer of another text on law, which was itself taken up by the Fifth Dalai Lama and copied several times during the early years of his new regime. Almost identical texts were then reproduced and distributed to administrators throughout the region. ${ }^{56}$ This was the closest that the central Tibetan regime

\footnotetext{
${ }^{54}$ F. Pirie, “The making of Tibetan law: the Khrims gnyis lta ba'i me long”, On a Day of a Month of a Fire Bird Year, J. Bischoff, P. Maurer, and C. Ramble (eds), Lumbini, International Research Institute, forthcoming.

${ }^{55}$ Between them, there is a section on the history of law in Tibet, which closely follows one of the recent historical narratives.

${ }^{56}$ These texts are generally referred to as the thirteen or sixteen zhal lce (literally, edicts). French, in The Golden Yoke, refers to them as 'law codes', although their form is similar to the text described here. Several manuscripts are kept in the Library of Tibetan Works and Archives, in Dharamsala, and there are others in the City of
} 
came to producing a general code of law.

Much of the interest of these developments lies in the combination of matters to which the Tibetan concept of trim was used to refer. Within the early empire, the trim were legalistic rules, which supported the centralizing projects of the government, making explicit a structured hierarchy. The writers of the subsequent historical narratives described the kings' laws as disciplinary, rather than administrative, rules, claiming that they were based on religious morality. A fourteenth-century treatise continued to claim a close association between religious and royal laws, now describing practices of mediation as 'the application' of the king's law. Bureaucracy was associated with legalism during the empire, that is; the political fragmentation and religious developments of the post-imperial period gave rise to a new and idealistic model of kingship, in which law was based on religious principles; while the introduction of new bureaucratic practices by the Yuan and attempts to centralize practice of conflict resolution, led to an association between law, government, and mediation. Later again, the trim of the Golok tribes were elaborate rules that reflected the mediation of blood feuds, while in Ladakh, the term became associated with unwritten village norms. It is evident that we need to keep these different phenomena analytically separate, if we are to understand Tibetan legal practices and ideas. Again, a lot more could be said about this complicated history, but what is striking, for present purposes, is the multiplicity of phenomena to which the Tibetan concept of trim applied: rules for compensation and punishment, rules for personal morality, penalties and discipline, governmental practices, and the moral symbolism of religious laws. This is not dissimilar from the range of phenomena to which the English concept of 'law' can refer, and it returns us to the question of how were are make sense of this variety.

An element of legalism is found in all the phenomena to which the Tibetan concept of trim is applied, albeit only very lightly in the case of the Ladakhi village customs. It is also evident that the legalism of the generalizing rules and abstract categories can, in turn, evoke a sense of higher abstract standards. In the historical narratives the laws were said to be central to the civilizing project of the Buddhist kings. In this way they represented an ideal form of government, onto which disparate and unsystematic practices of mediation could later be projected. In the Golok case the trim made explicit the principle of compensation and affirmed tribal identity and independence. In each context, the laws articulated moral values, whether the principles of Buddhist morality, appropriate measures of compensation, or tribal loyalty and bravery. They represented, at least indirectly, the justice of Tibetan responses to conflict.

The laws also did ideological work for kings, king-makers, and tribal leaders. In the fourteenth century, in particular, they seem to have been part of an attempt to establish more centralized administrative and governmental structures, a process that has considerable resonance with Roberts's discussion of the development of law. On his account, governments formulate ideological justification for their authority, followed by the elaboration of rules and means to ensure compliance. ${ }^{57}$ However, the Tibetan examples also demonstrate that the uses and appeal of legalism are not solely associated with centralizing governments. Laws were also invoked by the writers of religious histories, when the elaborate administrative structures of the empire were a distant memory, and they were created by tribespeople who resisted the expansionist aims of neighbouring political regimes. These disparate phenomena are united by the use of legalism, that is general rules and abstract categories. Even the edicts that describe mediation practices purport to concern the application of general laws. But they do so in very different ways and for different purposes.

Liverpool Museum. Printed versions are reproduced in Bod kyi snga rabs khrims srol yig cha bdams bsgrigs. Lhasa, Bod ljongs mi dmangs dpe skrun khang, 1989.

${ }^{57}$ Roberts, “After Government”. In practice, the Tibetans barely institutionalized their processes of justice. 
This brings us back to the themes of the opening section of this article.

\section{Law and legalism: themes and comparisons}

To return to our original questions, what is distinctive about legal rules, forms, and processes, and why does law seem to be and do so many things? What we need is not a theory that encompasses as many examples as possible, as some socio-legal scholars have argued, ${ }^{58}$ but a means to distinguish amongst them. The broader the subject-matter, the greater the need for analytic precision within it. I have argued that appeal to generalizing rules and abstract categories, that is the use of legalism, unites distinctively legal phenomena amongst the Tibetan examples. These examples also suggest an association between phenomena with legalistic, idealistic, and pragmatic aspects, which is not dissimilar from the English-speaking concept of law. But what explains the multiple functions of law and its attractions to different people in very different contexts?

Legalism, at its simplest, establishes rules, principles, and categories, which stand apart from practice and which can be used to order the messy reality of everyday life. As a style of thought and argument, it makes relations and distinctions explicit, specifying the categories into which things and people may fall, bringing social forms into focus and rendering them precise. ${ }^{59}$ As legal theorist Honoré puts it, law is concerned with the relations between human beings, but it transforms the data of ordinary life into those of a special drama, with its own persons, costumes and conventions. ${ }^{60}$ It categorizes actions, events, personalities, and conditions in a special way and draws conclusions as to the legal position of the dramatis personae and their mutual relations. As the anthropologist Sally Merry has also recognized, 'law works in the world not just by the imposition of rules and punishments but also by its capacity to construct authoritative images of social relationships and actions, images which are symbolically powerful. Law provides a set of categories and frameworks through which the world is interpreted'. ${ }^{61}$

The significance of this aspect of legal language is often overlooked by legal anthropologists. Goodale, for example, emphasizes law's 'instability', and what he describes as its 'heteroglossia' - the fact that 'legal discourse always embodies many voices, many competing perspectives, many registers of power' ${ }^{62}$ This may be true of court-room argument, in which everyday language is used to discuss real events, people, and relationships, but it is to miss the point about the language of the law. Laws impose explicit rules and categories on reality. It is this aspect of legalistic language, I have argued here, that the Ladakhi villagers resist, and it is because of the power of legalistic rules that so much effort is put into subverting it elsewhere. Many of the examples discussed by Goodale describe precisely this. ${ }^{63}$ At the same time, it is because they promote order according to a general framework, that laws can be used by the powerful to organise the world in their own interests. To overlook the legalism of the law and the nature of its language is to miss much of what makes it both distinctive and powerful.

\footnotetext{
58 Tamanaha, A General Jurisprudence of Law and Society; W. Twining, General Jurisprudence: Understanding Law from a Global Perspective, Cambridge, University Press, 2009.

${ }^{59}$ Pirie, The Anthropology of Law, ch. 6.

${ }^{60}$ A.M. Honoré, “Real Laws”, Law, Morality, and Society, P. M. S. Hacker and J. Raz (eds), Oxford, University Press, 1977, p. 112. This, in turn, makes possible the organized, critical reflection of jurisprudence and the type of deliberative reasoning typical of court judgments: P. Dresch, "Legalism, Anthropology, and History”, Legalism: Anthropology and History, Dresch and Skoda (eds), p. 1-37, at p. 15; Pirie, The Anthropology of Law, p. 141-42.

${ }^{61}$ S.E. Merry, Getting Justice and Getting Even: Legal Consciousness Among Working-Class Americans, Chicago, University Press, 1990, p. 8-9.

${ }^{62}$ Goodale, Anthropology and Law, p. 39.

63 Ibid. ch. 1.
} 
The focus on legalism, then, enables us to identify the role and force of law amidst the more complex processes with which it is inevitably entangled, and with which the anthropologists must also be concerned. At the same time, it opens up new insights into what law is and does. For the early Tibetan kings, the rules on hunting accidents made explicit an ordered hierarchy. For their judges, the same rules probably established principles about accident and intention, which they could apply in other cases. The Golok laws provided a system of measurement for lives and injuries on which decisions about compensation could be based, even if they were not directly applied. Laws are often, in these ways, symbolically important, as well as being tools of government and regulation: the representation of order can be as important as the practical organization of social relations. As Dresch puts it, legalistic thought addresses the world through legal categories and rules that stand apart from the flux of events and personalities. ${ }^{64}$ The world can then be classified in a way that allows for the explicit discussion of moral order. In many cases laws invoke higher ideals, as the writers of the Tibetan narratives did. They allow claims to be formulated in terms that project particular interests onto a wider moral sphere. This is obvious in the case of Islamic, Hindu, and other 'religious laws', or human rights provisions in the modern world; but even pragmatic rules about compensation, property, or family relations, allow claims to be projected onto an objective and ideal social order. The laws of the Golok tribespeople tell them that they are right to claim compensation for injuries and accept settlement, even when their norms of revenge point towards direct retaliation. At the same time, by claiming to be guardians of this legal order — as the tribes' ruling families did — the politically powerful can claim legitimacy for their status and activities.

This appeal to higher principles underlies the ideal of the 'rule of law'. This is the more abstract (and related) sense that laws represent standards with which even kings, rulers, and their governments ought to comply. It is sometimes thought of as a Western ideal, which supports the interests of modern states and reinforces their individualistic cultural values, but in fact it reflects a more ancient and fundamental aspect of much historical law. ${ }^{65}$ As many scholars have noted, law is not always just an instrument of the ruler, or a means to 'legitimize the take', although it may do these things. Many anthropologists have described the ways in which indigenous groups adopt human rights norms and arguments in an attempt to hold the powerful to account. ${ }^{66}$ The attraction of the law for these groups is only comprehensible if we appreciate what the law represents and the power of its language.

It is in the nature of law as explicit and generalizing rules that it can perform these dual functions, to both exercise power and resist it. The fact that the articulation of moral principles in legalistic terms sets them apart, giving them an independence and authority, explains many of the puzzles raised by the Comaroffs. ${ }^{67}$ Remarking on the rise of 'lawfare' in the modern world, they ask why people turn to courts and laws to pursue what are essentially political campaigns. This was the tactic of the Hawaiian Sovereignty Movement, described by Merry, which convened a quasi-legal tribunal to assert independence and autonomy, using legalistic language to hold the US to account. ${ }^{68}$ The appeal to legalistic language lifted the Movement's claims into a realm of universal legal principles, as it does for people everywhere. This is to evoke commitments that it is hard for governments, states, and other powerful actors to deny. It does not, of course, mean that such claims will always be successful-legal processes can be manipulated and subverted by the ruthless and

\footnotetext{
${ }^{64}$ Dresch, "Legalism, Anthropology, and History”, p. 15.

65 B. Tamanaha, On the Rule of Law, Cambridge, University Press, 2004.

${ }^{66}$ Goodale and Merry, The Practice of Human Rights.

${ }^{67}$ J. and J. Comaroff, "Introduction”, Law and Disorder in the Postcolony.

68 S.E. Merry, "Legal Pluralism and Transnational Culture: The Ka Ho'okolokolonui Kanaka Maoli Tribunal, Hawai'i, 1993”, Human Rights, Culture and Context, R.A. Wilson (ed.) London, Pluto Press, 1997, p. 28-48.
} 
unscrupulous, as well as those simply intent on pursuing their own interests-but it explains the attractions of legal argument and the rise of 'lawfare' among those who might otherwise have little use for legalism.

The themes that comes into view if we consider legalistic phenomena comparatively could be multiplied. A widespread feature of many laws is, for example, the extent to which they may be borrowed from elsewhere, rather than crystallised out of unwritten norms and practices: law-makers often emulate other traditions because they wish to indicate participation in a wider moral world, and this is as true of financiers in contemporary Japan as it was of the Golok tribespeople. ${ }^{69}$ None of this is to define precisely what law is, but it is to ask about the features of what is distinctively legal amidst the great variety of forms and processes described by legal anthropologists.

\section{Conclusion}

Historians offer us a wealth of valuable examples to set alongside the case studies of anthropologists, and through which we can explore what law is and does. They point to the importance of legalism as a means of identifying what is distinctively legal within the wide category of legal phenomena, and a basis for comparison amongst them.

In a world dominated by forms of law with European roots and the pressing problems of migration and exclusion, justice and human rights, power, and domination, it can be tempting to concentrate on contemporary forms and avoid more critical questions about what law is and does. But it has long been the success of anthropology to use marginal examples to throw such questions more effectively into relief. In the case of law, written records allow us to add historical evidence of the ways in which law has been significant to those who have made, preserved, used, or resisted it. Using historical examples to ask about the nature of law highlights form as well as function, and the symbolic and expressive qualities of legalistic phenomena. It helps to make sense of the complicated relationship between law and power, and the paradoxical ways in which laws are invoked by those who would claim justice and resist the domination of the powerful. These dynamics were as important to the peoples of ancient civilizations as they are to those concerned with human rights and the rule of law in the contemporary world.

${ }^{69}$ Pirie, The Anthropology of Law, 176-78; Riles, “Collateral Knowledge”. 